\begin{tabular}{l|l}
\hline Potaice & e-ISSN: 2655-9404 p-ISSN: 2721-8376 \\
Vol. 3 No. 3, Oktober 2020 & DOI: 10.20473/ntr.v3i3.22834 \\
\hline
\end{tabular}

Article history: Submitted 27 July 2020; Accepted 2 September 2020; Available online 1 October 2020.

\title{
Penguasaan Hak Atas Tanah yang Belum Bersertipikat
}

\author{
Mohamad Da'i Efendi \\ mohamad.dai.efendi-2016@fh.unair.ac.id \\ Universitas Airlangga
}

\begin{abstract}
Research "Uncertified Control of Land Rights" which is used in the normative juridical research method by invitation, conceptual approach, and case approach. Land registration is mandatory for land rights owners to obtain recognition of rights and to obtain strong evidence of land ownership, namely in the form of a certificate. There are still many lands in Indonesia that are not yet certified and other legal actions from these lands make the potential for disputes even greater. Land registration is regulated in Government Regulation No. 24/1997 on Land Registration. Mastery of land parcels is limited to physical control without written evidence the land owner does not have legal protection if there is a dispute. However, the tenure of the tenure can serve as the basis for first-time land registration, which results in a certificate. Land that is only physically controlled without written evidence can still be transferred, especially through buying and selling, and is legally valid as long as it fulfills the concepts and requirements contained in the Legislation by making deeds in the PPAT. Keywords: Land Registration; Certificate; Sale and Purchase.
\end{abstract}

\begin{tabular}{l} 
Abstrak \\
\hline Penelitian "Penguasaan Hak Atas Tanah yang Belum Bersertipikat" yang dalam \\
penulisannya menggunakan metode penelitian yuridis normatif dengan pendekatan \\
perundang-undangan, pendekatan konseptual, dan pendekatan kasus. Pendaftaran \\
tanah merupakan hal wajib bagi pemilik hak atas tanah untuk memperoleh pengakuan \\
hak dan untuk memperoleh bukti kuat kepemilikan tanah, yaitu berupa sertipikat. \\
Masih banyak tanah di Indonesia yang belum bersertipikat dan perbuatan hukum \\
lainnya dari tanah tersebut membuat potensi akan terjadinya sengketa semakin besar. \\
Pendaftaran tanah diatur dalam Peraturan Pemerintah Nomor 24 tahun 1997 tentang \\
Pendaftaran Tanah. Penguasaan bidang tanah yang hanya sebatas menguasai secara \\
fisik tanpa adanya bukti tertulis menjadikan pemilik tanah tidak memiliki perlindungan \\
hukum jika nantinya ada sengketa. Namun, jangka waktu lamanya penguasaan bisa \\
dijadikan sebagai dasar untuk dilakukannya pendaftaran tanah untuk pertama kali, \\
yang hasilnya akan memperoleh sertipikat. Tanah yang hanya dikuasai secara fisik \\
tanpa adanya bukti tertulis tetap bisa dilakukan peralihan khususnya melalui jual \\
beli, dan sah hukumnya selama memenuhi konsep dan persyaratan yang terdapat \\
pada Peraturan Perundang-undangan yakni dengan pembuatan akta di PPAT. \\
Kata Kunci: Pendaftaran Tanah; Sertipikat; Jual Beli.
\end{tabular}




\section{Pendahuluan}

Indonesia merupakan negara kepulauan dengan total pulau sejumlah 16.056 pada tahun 2019. ${ }^{1}$ Pasal 19 ayat (1) UUPA menyebutkan bahwa untuk menjamin kepastian hukum oleh pemerintah diadakan pendaftaran tanah di seluruh wilayah Republik Indonesia menurut ketentuan yang diatur dengan Peraturan Pemerintah. Pemerintah telah menerbitkan Peraturan Pemerintah No. 10 tahun 1961 tentang pendaftaran tanah yang kemudian diganti dengan Peraturan Pemerintah No.24 tahun 1997 tentang pendaftaran tanah. Yang dimaksud pendaftaran tanah adalah suatu rangkaian kegiatan yang dilakukan pemerintah secara terus-menerus, berkesinambungan dan teratur meliputi pengumpulan, pengolahan, pembukuan, dan penyajian serta pemeliharaan data fisik dan data yuridis, dalam bentuk peta dan daftar mengenai bidang - bidang tanah dan satuan rumah susun, termasuk pemberian surat tanda bukti haknya bagi bidang - bidang tanah yang sudah ada haknya dan hak milik atas satuan rumah susun serta hak - hak tertentu yang membebaninya.

Pelaksanaan pendaftaran tanah di Indonesia belum dapat diwujudkan sepenuhnya. Di Indonesia terdapat126juta bidang tanah, namun sampai tahun 2016 baru 46 juta bidang tanah yang terdaftar di Kementerian Agraria dan Tata Ruang / Badan Pertanahan Nasional (kemudian disebut dengan Kementerian ATR/BPN), masih kurang 80 juta bidang tanah yang belum terdaftar. Sebelum tahun 2017 Kementerian ATR/BPN setiap tahunnya hanya mampu mensertipikatkan tanah sebanyak 500.000 - 800.000 bidang, itu berarti membutuhkan waktu lebih dari 100 tahun untuk dapat mensertipikatkan tanah seluruh Indonesia. Mulai tahun 2017, kementerian ATR/BPN melaksanakan program sertipikat massal. Hasilnya cukup signifikan, dari tahun ke tahun mengalami peningkatan. Dari tahun 2017 berhasil mensertipikatkan 5 juta bidang tanah, tahun 2018 seluas 7 juta bidang tanah, tahun

1 Direktorat Jenderal Bina Administrasi Kewilayahan, 'Data Rekapitulasi Jumlah Pulau' <https:// ditjenbinaadwil.kemendagri.go.id/wp-content/uploads/2019/01/3.-Data-RekapitulasiJumlah-Pulau> accessed 27 August 2019. 
2019 seluas 9 juta bidang tanah. Target 5 tahun kedepan bisa mensertipikatkan 10 juta bidang tanah tiap tahunnya, sehingga target di tahun 2025 seluruh tanah di Indonesia sudah bersertipikat. ${ }^{2}$

Upaya pemerintah dalam mempercepat pensertipikatan bidang tanah yaitu melalui program Pendaftaran Tanah Sistematis Lengkap atau disebut PTSL. Pengertian PTSL dijelaskan dalam pasal 1 angka 2 Peraturan Menteri Agraria/ Kepala BPN No. 6 tahun 2018, Pendaftaran Tanah Sistematis Lengkap yang selanjutnya disingkat PTSL adalah kegiatan Pendaftaran Tanah untuk pertama kali yang dilakukan secara serentak bagi semua objek Pendaftaran Tanah di seluruh wilayah Republik Indonesia dalam satu wilayah desa/kelurahan atau nama lainnya yang setingkat dengan itu, yang meliputi pengumpulan data fisik dan data yuridis mengenai satu atau beberapa objek Pendaftaran Tanah untuk keperluan pendaftarannya. Hasil dari program PTSL hingga tahun 2019 tercatat berhasil mensertipikatkan 67 juta bidang tanah dari total 126 juta bidang tanah. Sementara 59 juta bidang tanah belum bersertipikat. Hal ini mengartikan bahwa masih banyak bidang tanah di Indonesia yang belum terdaftar dan belum mendapat kepastian hukum.

Dampak dari banyaknya tanah yang belum terdaftar adalah munculnya masalah pertanahan yang semakin beragam. Penyebab terbesar ialah belum terdaftarnya bidang tanah secara menyeluruh, bahkan yang sudah terdaftarpun masih terjadi masalah apalagi yang belum atau yang tidak di daftar, sehingga belum tercipta kepastian dan perlindungan hukum terhadap hak-hak atas tanah yang dimiliki oleh masyarakat dan bahkan Negara. ${ }^{3}$ Fakta di masyarakat masih banyak sengketa tanah yang bermula dari belum terciptanya kepastian hukum bidang tanah seperti masih ditemukannya sengketa pertanahan sebagai akibat dari belum terdaftarnya hak atas tanah. Terbatasnya pengetahuan masyarakat menjadi salah satu sebab untuk tidak mendaftarkan tanahnya. Kemudian tidak

\footnotetext{
2 Kementerian ATR/BPN, 'Infografis Pendaftaran Data Pendaftaran Tanah Di Indonesia' <https:/ / www.atrbpn.go.id/Berita/Infografis> accessed 29 August 2019.

3 M. Yamin Lubis dan Abd. Rahim Lubis, Hukum Pendaftaran Tanah (Mandar Maju 2018).[7].
} 
adanya bukti tertulis yang membuktikan bahwa yang bersangkutan telah memiliki hak atas tanah atau dalam artian hanya menguasai bidang tanah secara fisik tanpa bukti tertulis, juga menjadi penyebab tanah tidak segera didaftarkan. Bagaimana peraturan perundang-undangan mengatur pendaftaran tanah bagi bidang tanah yang hanya dikuasai secara fisik tanpa bukti tertulis, nampaknya masih belum tersampaikan kepada masyarakat.

Dalam realitas kehidupan di masyarakat khususnya di pedesaan, banyak terjadi transaksi jual beli terhadap tanah yang belum bersertipikat. Ditambah lagi proses transaksi yang hanya dilakukan pencatatan dibawah tangan tanpa adanya legalitas dari pejabat yang berwenang mengurusi. Keabsahan dari prosedur jual beli terhadap tanah yang belum bersertipikat dan jual beli tanah yang dilakukan tanpa keterlibatan pejabat yang berwenang sesuai peraturan perundang-undangan masih dipertanyakan. Belum diketahui pasti apa yang akan terjadi jika suatu saat terjadi sengketa terhadap bidang tanah yang proses jual belinya tidak dilakukan di pejabat yang berwenang. Penelitian ini hanya membahas mengenai tanah hak, dan tidak membahas mengenai tanah negara.

Penelitian ini merupakan penelitian yuridis normatif. Menurut Soerjono Soekanto adalah penelitian hukum yang dilakukan dengan cara meneliti bahan pustaka atau data sekunder sebagai bahan dasar untuk diteliti dengan cara mengadakan penelusuran terhadap peraturan-peraturan dan literatur-literatur yang berkaitan dengan permasalahan yang diteliti. ${ }^{4}$ Dan dalam melakukan pendekatan masalah dalam penelitian ini, penulis menggunakan 3 pendekatan yaitu pendekatan peraturan perundang-undangan (statute approach), pendekatan konseptual (conceptual approach), dan pendekatan kasus (case approach).

\section{Pendaftaran Tanah Di Indonesia}

Ketentuan Pasal 19 ayat (1) UUPA menyebutkan bahwa pelaksana pendaftaran tanah ialah pemeritah, kemudian diperjelas dalam pasal 5 PP No.

\footnotetext{
${ }^{4}$ Soerjono Soekanto \& Sri Mamudji, Penelitian Hukum Normatif (Suatu Tinjauan Singkat) (Rajawali Pers 2001).[13-14].
} 
24 tahun 1997 bahwa instansi yang diberi kewenangan untuk melaksanakan pendaftaran tanah ialah Badan Pertanahan Nasional (BPN) dan pada pasal 6 disebutkan bahwa dalam rangka penyelenggaraan pendaftaran tanah tersebut, tugas pelaksanaannya dilakukan oleh Kepala Kantor Pertanahan Kabupaten/ Kota. Badan Pertanahan Nasional (BPN) diatur dalam Peraturan Presiden nomor 10 tahun 2006 tentang Badan Pertanahan Nasional. ${ }^{5}$

Struktur organisasi dari Badan Pertanahan dibagi menjadi 3 (tiga) bagian sesuai dengan tingkat wilayah. Ditingkat pusat ada Badan Pertanahan Nasional Republik Indonesia atau disingkat BPNRI. Di tingkat provinsi ada Kantor Wilayah Badan Pertanahan Nasional Provinsi atau biasa disebut Kanwil BPN Provinsi. Dan yang terakhir di tingkat Kabupaten/Kota ada Kantor Pertanahan Kabupaten/Kota. Ketiga struktur tersebut berkedudukan saling koordinasi satu sama lain dibawah komando dari pusat. Kepala Kantor Pertanahan dibantu oleh Pejabat Pembuat Akta Tanah (PPAT) dan pejabat lain yang ditugaskan untuk melaksanakan kegiatan-kegiatan tertentu menurut peraturan perundangundangan. PPAT diangkat dan diberhentikan oleh Menteri, dan diatur sendiri dalam Peraturan Pemerintah tentang Pejabat Pembuat Akta Tanah atau disingkat PPAT. 6

Tujuan diselenggarakannya pendaftaran tanah ialah untuk memberikan jaminan kepastian hukum dan perlindungan hukum kepada pemegang hak atas tanah, untuk menyediakan infomasi kepada pihak-pihak yang berkepentingan, dan untuk terselenggaranya tertib administrasi pertanahan. Pendaftaran tanah memiliki 5 asas yang disebutkan dalam pasal 2 PP No. 24 tahun 1997, yaitu asas sederhana, asas aman, asas terjangkau, asas mutakhir, dan asas terbuka. Objek pendaftaran tanah meliputi hak milik, hak guna bangunan, hak guna usaha, hak pakai, tanah hak pengelolaan, tanah wakaf, hak milik atas satuan rumah susun, hak tanggungan, dan tanah negara.

Unsur-unsur yang terdapat dalam pelaksanaan pendaftaran tanah yaitu,

5 Urip Santoso, Pendaftaran Dan Peralihan Hak Atas Tanah (Prenamedia Group 2010).[23].

6 ibid.[23-24]. 
adanyaserangkaiankegiatan, dilakukanoleh pemerintah, secaraberkesinambungan atau terus menerus, secara teratur, bidang-bidang tanah, pemberian surat tanda bukti hak, dan hak-hak tertentu yang membebaninya. ${ }^{7}$ Pada teknisnya kegiatan pendaftaran tanah ini meliputi beberapa komponen, Pertama, pendaftaran tanah dilakukan secara terus menerus, artinya tiap kali terjadi perubahan atau peralihan atas tanah maupun subjeknya maka harus disertai dengan pendaftaran tanah. Kedua, adanya kegiatan pengumpulan data, baik data fisik maupun data yuridis. Data fisik meliputi luas tanah, batas-batasnya, serta bangunan dan tanaman yang ada diatasnya. Data yuridis meliputi nama hak atas tanah, nama pemegang haknya, peralihan dan pembebanannya. Ketiga, adanya tujuan tertentu, yaitu pendaftaran bertujuan untuk menjamin kepastian hukum (legal cadastre) dan sebagai dasar pemungutan pajak (fiscal cadastre). Keempat, kegiatan penerbitan surat tanda bukti hak, yang berisi tentang data yuridis dan surat ukur yang memuat data fisik hak, dan nantinya diserahkan kepada setiap pemegang hak atau pihak lain yang dikuasakan olehnya. ${ }^{8}$ Pendaftaran tanah terbagi menjadi 2 rangkaian kegiatan, yang pertama yaitu kegiatan pendaftaran tanah untuk pertama kali dan yang kedua yakni pemeliharaan data pendaftaran tanah. Pasal 12 ayat (1) PP No. 24 tahun 1997 menyebutkan, secara garis besar kegiatan pendaftaran tanah untuk pertama kali meliputi:

a. Pengumpulan dan pengolahan data fisik;

b. Pembuktian hak dan pembukuannya;

c. Penerbitan sertipikat;

d. Penyajian data fisik dan data yuridis;

e. Penyimpanan daftar umum dan dokumen.

Sedangkan untuk rangkaian kegiatan pemeliharaan data pendaftaran tanah disebutkan meliputi:

a. Pendaftaran peralihan dan pembebanan hak;

b. Pendaftaran perubahan data pendaftaran tanah lainnya.

Proses pendaftaran tanah untuk pertama kali dilakukan dengan

\footnotetext{
7 ibid.[14-16].

8 Samun Ismaya, Hukum Administrasi Pertanahan (Graha Ilmu 2013).[93].
} 
mengumpulkan dan mengolah data fisik. Kegiatan ini berupa pengukuran dan pemetaan bidang tanah. Sesuai dengan pasal 14 ayat (2) PP No. 24 tahun 1997 bahwa proses ini terbagi menjadi beberapa kegiatan yang dijabarkan antara pasal 15 sampai dengan pasal 22, yaitu :

a. Pembuatan peta dasar pendaftaran;

b. Penetapan batas bidang-bidang tanah;

c. Pengukuran dan pemetaan bidang-bidang tanah dan pembuatan peta pendaftaran;

d. Pembuatan daftar tanah;

e. Pembuatan surat ukur;

f. Pembuktian hak.

\section{Pendaftaran Tanah Untuk Pertama Kali}

Pendaftaran tanah untuk pertama kali dibagi menjadi dua metode, yaitu pendaftaran tanah secara sporadik dan pendaftaran tanah secara sistematik. yang dimaksud dengan pendaftaran tanah secara sistematik adalah kegiatan pendaftaran tanah untuk pertama kali yang dilakukan secara serentak yang meliputi objek pendaftaran tanah secara keseluruhan yang belum terdaftar dalam suatu wilayah atau bagian wilayah suatu desa/kelurahan. Pendaftaran tanah secara sistematik dilakukan berdasarkan suatu rencana kerja dan pelaksanaanya di wilayahwilayah yang telah ditetapkan oleh Kementerian ATR/BPN. Pendaftaran tanah secara sistematik dilakukan melalui ajudikasi, yaitu kegiatan yang dilaksanakan dalam rangka proses pendaftaran tanah untuk pertama kali meliputi serangkaian kegiatan yakni, pengumpulan dan penetapan kebenaran data fisik dan data yuridis mengenai satu atau beberapa objek pendaftaran tanah untuk keperluan pendaftarannya. Penyelenggara pendaftaran secara sistematik ini adalah Badan Pertanahan Nasional, dan tugas pelaksanaan pendaftaran tanah secara sistematik dilaksanakan oleh Kepala Kantor Pertanahan Kabupaten/Kota. Dalam kegiatankegiatan tertentu yang disebutkan dalam peraturan perundang-undangan, Kepala Kantor Pertanahan Kabupaten/Kota melibatkan pejabat lain untuk membantu proses pendaftaran secara sistematik, diantaranya Pejabat Pembuat Akta Tanah (PPAT), Panitia Ajudikasi, Pejabat Pembuat Akta Ikrar Wakaf (PPAIW), pejabat 
dari kantor lelang, dan Kepala Desa/ kelurahan. ${ }^{9}$ Berikut rangkaian kegiatan pendaftaran tanah secara sistematik menurut PP No. 24 tahun 1997 dan Permen Agraria/Kepala BPN No. 3 tahun 1997:

Tabel 1. Prosedur pendaftaran tanah sistematik

\begin{tabular}{|c|c|c|}
\hline No. & $\begin{array}{l}\text { Peraturan Pemerintah } \\
\quad \text { No. } 24 \text { tahun } 1997\end{array}$ & $\begin{array}{l}\text { Permen Agraria/Kepala BPN } \\
\text { No. } 3 \text { tahun } 1997\end{array}$ \\
\hline 1. & Adanya suatu rencana kerja (Pasal 12 ayat 2 ) & Penetapan lokasi (Pasal 46) \\
\hline 2. & Pembentukan panitia ajudikasi (pasal 8) & Persiapan (Pasal 47) \\
\hline 3. & $\begin{array}{l}\text { Pembuatan peta dasar pendaftaran (Pasal 15- } \\
\text { 16) }\end{array}$ & Pembentukan panitia ajudikasi (Pasal 48) \\
\hline 4. & $\begin{array}{l}\text { Penetapan batas bidang-bidang tanah (Pasal } \\
\text { 17-19) }\end{array}$ & $\begin{array}{l}\text { Penyelesaian permohonan yang ada pada } \\
\text { saat mulainya pendaftaran tanah secara } \\
\text { sistematik (Pasal 55) }\end{array}$ \\
\hline 5. & Pembuatan peta dasar pendaftaran (Pasal 20) & Penyuluhan (Pasal 56) \\
\hline 6. & Pembuatan daftar tanah (Pasal 21) & Pengumpulan data fisik (Pasal 57-58) \\
\hline 7. & Pembuatan surat ukur (Pasal 22) & $\begin{array}{l}\text { Pengumpulan dan penelitian data yuridis } \\
\text { (Pasal 59-62) }\end{array}$ \\
\hline 8. & $\begin{array}{l}\text { Pengumpulan dan penelitian data yuridis } \\
\text { (Pasal 24-25) }\end{array}$ & $\begin{array}{l}\text { Pengumuman sekaligus pengesahan data } \\
\text { fisik dan data yuridis (63-64) }\end{array}$ \\
\hline 9. & $\begin{array}{l}\text { Pengumuman hasil penelitian data yuridis dan } \\
\text { hasil pengukuran (Pasal 26-27) }\end{array}$ & $\begin{array}{l}\text { Penegasan konversi, pengakuan hak, dan } \\
\text { pemberian hak (Pasal 65-66) }\end{array}$ \\
\hline 10. & $\begin{array}{l}\text { Pengesahan hasil pengumuman penelitian } \\
\text { data fisik dan data yuridis (Pasal 28) }\end{array}$ & Pembukuan hak (Pasal 67-68) \\
\hline 11. & Pembukuan hak (Pasal 29) & Penerbitan sertipikat (69-71) \\
\hline 12. & Penerbitan sertipikat (Pasal 31) & \\
\hline
\end{tabular}

Pasal 1 angka 11 PP No. 24 tahun 1997, yang dimaksud dengan pendaftaran tanah secara sporadik adalah kegiatan pendaftaran tanah untuk pertama kali mengenai satu atau beberapa objek pendaftaran tanah dalam wilayah atau bagian wilayah suatu desa/kelurahan secara individual atau massal. Kegiatan pendaftaran tanah secara sporadik dilakukan atas permohonan yang bersangkutan, artinya pemegang hak harus punya inisiatif sendiri untuk mengajukan permohonan pendaftaran tanah. Pendaftaran tanah secara sporadik bisa dilakukan dengan dua cara, cara yang pertama yaitu secara individual atau perseorangan, dan yang kedua yaitu dengan kolektif atau massal dari pemegang bidang tanah atau yang kuasanya. Penyelenggara dari pendaftaran tanah secara sporadik adalah Badan

\footnotetext{
${ }^{9}$ Urip Santoso (n 5). Op.Cit.[137].
} 
Pertanahan Nasional (BPN), yaitu lembaga pemerintah non depertemen yang bertanggungajawab kepada presiden. Sementara tugas pelaksanaan pendaftaran dilakukan oleh Kepala Kantor Pertanahan Kabupaten/Kota dengan dibantu oleh pejabat lain diantaranya, Panitia a, Pejabat Pembuat Akta Tanah (PPAT), Kepala Desa, dan Kepala Kecamatan. Berikut rangkaian kegiatan pendaftaran tanah sporadik menurut PP No. 24 tahun 1997 dan Permen Agraria/Kepala BPN No. 3 tahun 1997:

Tabel 2. Prosedur pendaftaran tanah sporadik

\begin{tabular}{|c|c|c|}
\hline No. & $\begin{array}{l}\text { Peraturan Pemerintah } \\
\text { No. } 24 \text { tahun } 1997\end{array}$ & $\begin{array}{c}\text { Permen Agraria/Kepala BPN } \\
\text { No. } 3 \text { tahun } 1997\end{array}$ \\
\hline 1. & $\begin{array}{l}\text { Dilakukan atas permintaan pihak yang } \\
\text { berkepentingan (Pasal } 13 \text { ayat } 4 \text { ) }\end{array}$ & $\begin{array}{l}\text { Permohonan pendaftaran tanah secara spo- } \\
\text { radik (Pasal 73-76) }\end{array}$ \\
\hline 2. & $\begin{array}{l}\text { Pembuatan peta dasar pendaftaran (Pasal } 15 \\
\text {-16) }\end{array}$ & Pengukuran (Pasal 77-81) \\
\hline 3. & $\begin{array}{l}\text { Penetapan batas bidang-bidang tanah (Pasal } \\
17-19)\end{array}$ & $\begin{array}{l}\text { Pengumpulan dan penelitian data yuridis } \\
\text { (Pasal 81-85) }\end{array}$ \\
\hline 4. & $\begin{array}{l}\text { Pengukuran dan pemetaan bidang-bidang } \\
\text { tanah (Pasal 20) }\end{array}$ & $\begin{array}{l}\text { Pengumuman sekaligus pengesahan data } \\
\text { fisik dan data yuridis (Pasal 86-87) }\end{array}$ \\
\hline 5. & Pembuatan daftar tanah (Pasal 21-24) & $\begin{array}{l}\text { Penegasan konversi dan pengakuan hak } \\
\text { (Pasal 88) }\end{array}$ \\
\hline 6. & Pembuatan surat ukur (Pasal 22) & Pembukuan hak (Pasal 89-90) \\
\hline 7. & Pembuktian hak baru (Pasal 23) & Penerbitan sertipikat (Pasal 91-93) \\
\hline 8. & Pembuktian hak lama (Pasal 24-25) & \\
\hline 9. & $\begin{array}{l}\text { Pengumuman hasil peneltian data yuridis } \\
\text { dan hasil pengukuran (Pasal 26-27) }\end{array}$ & \\
\hline 10. & $\begin{array}{l}\text { Pengesahan hasil pengumuman penelitian } \\
\text { data yuridis dan data fisik (Pasal 28) }\end{array}$ & \\
\hline 11. & Pembukuan hak (Pasal 29-30) & \\
\hline 12. & Penerbitan sertipikat (Pasal 31) & \\
\hline
\end{tabular}

Dari kegiatan kedua jenis pendaftaran tersebut, baik pendaftaran secara sistematik maupun secara sporadik sama-sama menghasilkan dokumen yang memberikan jaminan hukum yaitu berupa sertipikat. Sertipikat ialah surat tanda bukti hak yang berlaku sebagai alat pembuktian yang kuat mengenai data fisik dan data yuridis yang termuat di dalamnya, sepanjang data fisik dan data yuridis tersebut sesuai dengan data yang ada dalam surat ukur dan buku tanah hak yang bersangkutan. Dalam Pasal 19 ayat (2) huruf c UUPA dan Pasal 32 ayat (1) PP No. 24 tahun 
1997 memberi ketentuan bahwa sertifikat berfungsi sebagai alat bukti hak atas tanah dan berlaku sebagai alat pembuktian yang kuat. Sertifikat sebagai alat bukti hak atas tanah diterbitkan oleh Kantor Pertanahan Kabupaten/Kota melalui suatu proses pendaftaran tanah. ${ }^{10}$ Sertipikat hanya diserahkan kepada pihak yang namanya tercantum dalam buku tanah yang bersangkutan sebagai pemegang hak, atau kepada pihak lain yang mendapat kuasa olehnya.

Sertifikat yang mempunyai kedudukan sebagai akta otentik mempunyai kekuatan pembuktian lahir, formil dan materil dan berdasarkan Pasal 165 HIR bahwa akta otentik mempunyai kekuatan yang sempurna. Artinya apa yang tercantum didalamnya harus diterima sebagai suatu yang benar selama tidak ada pihak yang dapat membuktikan sebaliknya. ${ }^{11}$

\section{Pendaftaran Tanah Yang Hanya Dikuasai Secara Fisik Tanpa Bukti Tertulis}

Untuk keperluan pendaftaran haknya, dibuktikan dengan alat-alat bukti mengenai adanya hak tersebut berupa bukti-bukti tertulis, keterangan saksi dan atau pernyataan yang bersangkutan yang kadar kebenarannya dianggap cukup untuk dilakukan pendaftaran hak. Alat bukti tertulis yang dimaksud, disebutkan dalam penjelasan pasal 24, diantaranya :

a. grosse akta hak eigendom yang diterbitkan berdasarkan Overschrijvings Ordonnantie (S.1834-27), yang telah dibubuhi catatan, bahwa hak eigendom yang bersangkutan dikonversi menjadi hak milik, atau

b. grosse akta hak eigendom yang diterbitkan berdasarkan Overschrijvings Ordonnantie (S.1834-27) sejak berlakunya UUPA sampai tanggal pendaftaran tanah dilaksanakan menurut Peraturan Pemerintah Nomor 10 Tahun 1961 di daerah yang bersangkutan; atau

c. surat tanda bukti hak milik yang diterbitkan berdasarkan Peraturan Swapraja yang bersangkutan, atau

d. sertipikat hak milik yang diterbitkan berdasarkan Peraturan Menteri Agraria Nomor 9 Tahun 1959, atau

e. surat keputusan pemberian hak milik dari Pejabat yang berwenang, baik sebelum ataupun sejak berlakunya UUPA, yang tidak disertai kewajiban untuk

\footnotetext{
${ }^{10}$ Ilyas Ismail, 'Sertifikat Sebagai Alat Bukti Hak Atas Tanah Dalam Proses Peradilan' [2011] XIII Kanun Jurnal Ilmu Hukum.[53].

11 ibid.[29].
} 
mendaftarkan hak yang diberikan, tetapi telah dipenuhi semua kewajiban yang disebut didalamnya, atau

f. petuk Pajak Bumi/Landrente, girik, pipil, kekitir dan Verponding Indonesia sebelum berlakunya Peraturan Pemerintah Nomor 10 Tahun 1961, atau

g. akta pemindahan hak yang dibuat dibawah tangan yang dibubuhi tanda kesaksian oleh Kepala Adat/Kepala Desa/Kelurahan yang dibuat sebelum berlakunya Peraturan Pemerintah ini dengan disertai alas hak yang dialihkan, atau

h. akta pemindahan hak atas tanah yang dibuat oleh PPAT, yang tanahnya belum dibukukan dengan disertai alas hak yang dialihkan, atau

i. akta ikrar wakaf/surat ikrar wakaf yang dibuat sebelum atau sejak mulai dilaksanakan Peraturan Pemerintah Nomor 28 Tahun 1977 dengan disertai alas hak yang diwakafkan, atau

j. risalah lelang yang dibuat oleh Pejabat Lelang yang berwenang, yang tanahnya belum dibukukan dengan disertai alas hak yang dialihkan, atau

k. surat penunjukan atau pembelian kaveling tanah pengganti tanah yang diambil oleh Pemerintah atau Pemerintah Daerah, atau

1. surat keterangan riwayat tanah yang pernah dibuat oleh Kantor Pelayanan Pajak Bumi dan Bangunan dengan disertai alas hak yang dialihkan, atau

m.lain-lain bentuk alat pembuktian tertulis dengan nama apapun juga sebagaimana dimaksud dalam Pasal II, VI dan VII Ketentuan-ketentuan Konversi UUPA.

Tanah yang tidak terdapat bukti tertulis sebagaimana disebutkan dalam pasal 24, tanah tetap bisa dilakukan pendaftaran tanah. PP No. 24 tahun 1997 dan Permen Agraia/Kepala BPN No. 3 tahun 1997 mengatur mengenai pendaftaran tanah bagi yang tidak ada bukti tertulisnya,

\section{Pasal 24 Ayat (1) PP No. 24 tahun 1997}

Untuk keperluan pendaftaran hak, hak atas tanah yang berasal dari konversi hak-hak lama dibuktikan dengan alat-alat bukti mengenai adanya hak tersebut berupa bukti-bukti tertulis, keterangan saksi dan atau pernyataan yang bersangkutan yang kadar kebenarannya oleh Panitia Ajudikasi dalam pendaftaran tanah secara sistematik atau oleh Kepala Kantor Pertanahan dalam pendaftaran tanah secara sporadik, dianggap cukup untuk mendaftar hak, pemegang hak dan hak-hak pihak lain yang membebani-nya.

\section{Pasal 24 Ayat (2) PP No. 24 tahun 1997}

Dalam hal tidak atau tidak lagi tersedia secara lengkap alat-alat pembuktian sebagaimana dimaksud pada ayat (1), pembukuan hak dapat dilakukan 
berdasarkan kenyataan penguasaan fisik bidang tanah yang bersang-kutan selama 20 (dua puluh) tahun atau lebih secara ber-turut-turut oleh pemohon pendaftaran dan pendahulu-pendahulunya, dengan syarat :

a. penguasaan tersebut dilakukan dengan itikad baik dan secara terbuka oleh yang bersangkutan sebagai yang berhak atas tanah, serta diperkuat oleh kesaksian orang yang dapat dipercaya;

b. penguasaan tersebut baik sebelum maupun selama pengumuman sebagaimana dimaksud dalam Pasal 26 tidak dipermasalahkan oleh masyarakat hukum adat atau desa/kelurahan yang bersangkutan ataupun pihak lainnya.

\section{Pasal 61 Ayat (1) Permen Agraria/Kepala BPN No. 3 tahun 1997}

Dalam hal kepemilikan atas sebidang tanah tidak dapat dibuktikan dengan alat pembuktian sebagaimana dimaksud dalam Pasal 60, maka penguasaan secara fisik atas bidang tanah yang bersangkutan selama 20 (dua puluh) tahun atau lebih secara berturut-turut oleh yang bersangkutan dan para pendahulu-pendahulunya sebagaimana dimaksud dalam Pasal 24 ayat (2) Peraturan Pemerintah Nomor 24 Tahun 1997 dapat digunakan sebagai dasar untuk pembukuan tanah tersebut sebagai milik yang bersangkutan.

\section{Pasal 76 ayat (3) Permen Agraria/ Kepala BPN No. 3 tahun 1997}

Dalam hal bukti-bukti mengenai kepemilikan tanah sebagaimana dimaksud pada ayat (1) dan (2) tidak ada maka permohonan tersebut harus disertai dengan:

a. surat pernyataan dari pemohon yang menyatakan hal-hal sebagai berikut:

1) bahwa pemohon telah menguasai secara nyata tanah yang bersangkutan selama 20 tahun atau lebih secara berturut-turut, atau telah memperoleh penguasaan itu dari pihak atau pihak-pihak lain yang telah menguasainya, sehingga waktu penguasaan pemohon dan pendahulunya tersebut berjumlah 20 tahun atau lebih;

2) bahwa penguasaan tanah itu telah dilakukan dengan itikad baik;

3) bahwa penguasaan itu tidak pernah diganggu gugat dan karena itu dianggap diakui dan dibenarkan oleh masyarakat hukum adat atau desa/kelurahan yang bersangkutan;

4) bahwa tanah tersebut sekarang tidak dalam sengketa; 
5) bahwa apabila pernyataan tersebut memuat hal-hal yang tidak sesuai dengan kenyataan, penandatangan bersedia dituntut di muka Hakim secara pidana maupun perdata karena memberikan keterangan palsu.

\section{Pasal 22 ayat (2) Permen ATR/Kepala BPN No. 6 tahun 2018}

Dalam hal bukti kepemilikan tanah masyarakat tidak lengkap atau tidak ada sama sekali maka dapat dilengkapi dan dibuktikan dengan surat pernyataan tertulis tentang pemilikan dan/atau penguasaan fisik bidang tanah dengan itikad baik oleh yang bersangkutan

Surat keterangan yang dimaksud dalam pasal-pasal tersebut ialah menerangkan bahwa jika bidang tanah sama sekali tidak terdapat bukti tertulis, maka pembukuan hak pembukuan hak dapat dilakukan berdasarkan kenyataan penguasaan fisik bidang tanah yang bersangkutan selama 20 (dua puluh) tahun atau lebih secara berturut-turut oleh pemohon pendaftaran dan pendahulupendahulunya, dengan syarat harus diketahui Kepala Desa dan keterangan dari minimal 2 (dua) orang saksi. Dengan ini, pemilik tanah yang menguasai hanya sebatas penguasaan fisik tanpa bukti tertulis dapat melakukan pendaftaran tanah sebagaimana telah diatur dalam peraturan perundang undangan.

\section{Peralihan Hak Atas Tanah Melalui jual Beli}

Pemindahan hak atas tanah dari pihak satu ke pihak lainnya bisa dilakukan melalui beberapa kegiatan, salah satunya adalah melalui transaksi jual beli. Peralihan hak atas tanah melalui jual beli berbeda dengan transaksi jual beli terhadap benda mati pada umumnya, jika benda mati lainnya seperti buku, mobil, yang berpindah tangan ialah mengenai benda tersebut. Dalam transaksi jual beli terhadap hak atas tanah yang berpindah ialah hak atas kepemilikan bidang tanah. ${ }^{12}$

Jual beli dalam Kamus Besar Bahasa Indonesia (KBBI) diartikan sebagai persetujuan saling mengikat antara penjual, yakni pihak yang menyerahkan barang, dan pembeli sebagai pihak yang membayar harga barang yang dijual. ${ }^{13}$

\footnotetext{
12 Urip Santoso (n 5). Op Cit.[358].

${ }^{13}$ Kamus Besar Bahasa Indonesia, 'Jual Beli' <https://www.kbbi.web.id/jual beli> accessed 12 April 2020.
} 
Dalam UUPA dan PP No. 24 tahun 1997 tentang pendaftaran tanah yang menjadi sumber primer penelitian ini, tidak menjelaskan secara rinci terkait jual beli tanah. saja pada pasal 37 PP No. 24 tahun 1997 menyebut kata jual beli, yang mana jual beli adalah salah satu dari perbuatan hukum pemindahan hak atas tanah, tidak menjelaskan terkait definisi dan prosedur pelaksanaan jual beli tanah. Boedi Harsono sebagaimana dikutip Urip Santoso, menyatakan bahwa jual beli tanah merupakan perbuatan hukum yang berupa penyerahan tanah untuk selamanya yang dilakukan oleh penjual kepada pembeli berbarengan dengan pembayaran yang dilakukan pmbeli kepada penjual tanah. ${ }^{14}$

Meskipun dalam UUPA tidak dijelaskan secara rinci terkait jual beli tanah, tetapi bisa diambil pemahaman terkait jual beli tanah dilihat dari dasar penyusunan UUPA yang berasal dari hukum adat, maka jual beli tanah dalam UUPA adalah menggunakan konsepsi, asas-asas, lembaga hukum, dan sistem yang dianut oleh hukum adat. Seperti halnya yang terdapat pada bunyi pasal 5 UUPA, yang mengindikasikan bahwa pengertian jual beli tanah hak milik menurut UUPA ialah merupakan jual beli menurut hukum adat. ${ }^{15}$ Bunyi pasal 5 UUPA:

"Hukum agraria yang berlaku atas bumi, air dan ruang angkasa ialah hukum adat, sepanjang tidak bertentangan dengan kepentingan nasional dan Negara, yang berdasarkan atas persatuan bangsa, dengan sosialisme Indonesia serta dengan peraturan-peraturan yang tercantum dalam Undangundang ini dan dengan peraturan perundangan lainnya,segala sesuatu dengan mengindahkan unsur-unsur yang bersandar pada hukum agama".

Dalam hukum adat, kegiatan jual beli tanah ini terdiri dari 3 macam jual beli, pertama jual lepas atau biasa disebut adol plas, yang berarti pemilik tanah menyerahkan tanahnya kepada pembeli untuk selama lamanya setelah dilakukan pembayaran oleh pembeli sesuai kesepakatan kedua pihak. Kedua, jual gadai atau disebut dengan istilah adol gadai. Jual gadai ini berlaku untuk tanah garapan pertanian atau sawah, dimana pemilik tanah memberikan tanahnya kepada orang lain untuk digarap dan pemilik tanah mendapatkan uang dari pemegang gadai.

\footnotetext{
${ }^{14}$ Urip Santoso (n 5). Op. Cit.[360].

15 Adrian Sutedi, Peralihan Hak Atas Tanah Dan Pendaftarannya ((Sinar Grafika 2010).[149].
} 
Ketiga, adalah jual tahunan atau disebut dengan istilah adol tahunan. Jual tahunan ini hampir sama dengan jual gadai, perbedaannya terletak pada masa garap yang dipakai yaitu masa panen. Pemilik tanah akan menerima uang dari penggarap tanah sesuai kesepakatan yang telah dilakukan. ${ }^{16}$

Jual beli tanah menurut hukum adat merupakan suatu perbuatan hukum pemindahan hak atas tanah yang memiliki sifat terang, riil, dan tunai. Terang memiliki arti bahwa pebuatan pemindahan hak atas tanah dilakukan di hadapan kepala adat atau atau kepala desa yang bertindak sebagai pejabat yang menanggung keteraturan dan sahnya transaksi, sehingga diketahui oleh umum. Riil berarti, kehendak atau niat yang diucapkan harus diikuti dengan perbuatan yang nyata menunjukkan tujuan jual beli tersebut. Sedangakan arti dari tunai ialah bahwa perbuatan pemindahan hak oleh penjual dan pembayaran oleh pembeli dilakukan dalam waktu yang bersamaan, baik pembayaran dilakukan tunai lunas atau dibayar sebagian. Jika di kemudian hari pembeli tidak melunasi pembayaran, maka penjual tidak dapat menuntut atas dasar terjadinya jual beli tanah, tetapi atas dasar hukum utang piutang. ${ }^{17}$

Konsep jual beli tanah hukum adat dengan KUH Perdata memiliki perbedaan dimana dalam pasal 1458 KUH Perdata yang menyatakan bahwa jual beli dianggap sudah terjadi antara kedua pihak ketika keduanya telah melakukan kesepakatan meskipun belum ada terjadi serah terima barang dan belum dilakukan pembayaran oleh pembeli kepada penjual. Jual beli tanah dalam hukum adat tidak bisa dikatakan sebagai perjanjian yang terdapat pada pasal 1457 KUH Perdata, akan tetapi jual beli tanah dalam hukum adat merupakan perbuatan hukum dengan itikad baik untuk memindahkan hak atas tanah dari penjual kepada pembeli, dan pembayaran dilakukan secara tunai serta dilakukan di hadapan ketua adat atau kepala desa. Objek peralihan hak atas taah melalui jual beli diantaranya, hak milik, hak guna bangunan, hak guna usaha, hak pakai, dan hak milik atas satuan rumah susun.

\footnotetext{
${ }^{16}$ Urip Santoso (n 5). Op.Cit.[360].

17 Adrian Sutedi (n 15). Op.Cit.[72].
} 


\section{Syarat Sah Jual Beli}

Jual beli hak atas tanah harus memenuhi dua syarat sah, yaitu syarat materil dan syarat formil. Syarat materiil meliputi penjual (pemilik tanah), penjual (calon pemilik tanah), dan objek jual beli tanah sebagaimana telah disebutkan dalam UUPA. Penjual adalah orang yang berhak untuk menjual hak atas tanah yang dalam kuasanya. Seseorang dikatakan sah untuk menjual tanahnya adalah seorang yang namanya tertera dalam sertipikat saja, atau dalam hal ini tidak terdapat sertipikat dapat dibuktikan dengan bukti yang lain sesuai peraturan perundang-undangan. Seorang penjual juga harus memenuhi ketentuan kecakapan dalam melakukan perbuatan hukum seperti halnya disebutkan dalam pasal 1330 KUH Perdata yang dimaksud cakap disini ialah yang sudah dewasa, yakni 21 tahun menurut KUH Perdata.

Sama halnya dengan penjual, pembeli harus memenuhi usia dewasa agar terpenuhinya syarat materiil ini. Terkait dengan pemegang hak atas tanah, UUPA mengatur berbeda mengenai subjek dan objek hak atas tanah. Subjek hukum ialah status hukum bagi calon pembeli, dan objek hukum ialah status hak yang ada pada tanah yang akan dijual. Jika tanah berstatus sebagai hak milik, maka calon pembeli yang diperbolehkan ialah perseorangan WNI, badan keagamaan, dan badan sosial. Jika objeknya berupa Hak Guna Usaha (HGU) dan Hak Guna Bangunan (HGB), maka calon pembelinya ialah perseorangan WNI dan badan hukum yang didirikan dan berkedudukan di Indonesia. Sedangkan untuk tanah hak pakai, selain perseorangan WNI yang berhak menjadi calon pembeli ialah warga negara asing yang berkedudukan di Indonesia dan badan hukum yang didirikan juga berkedudukan di Indonesia. Jika pembeli tidak sesuai ketentuan maka jual beli tanah dianggap batal demi hukum. Kemudian syarat sah materiil yang ketiga ialah objek jual beli tanah sebagaimana disebutkan dalam UUPA. Dipersyaratkan objek jua beli dalam keadaan bebas sengketa.

Syarat formal dari peralihan hak atas tanah melalui jual beli merupakan suatu formalitas transaksi jual beli tanah. Formalitas yang dimaksud ialah akta perjanjian jual beli yang dibuat di pejabat yang berwenang yakni Pejabat Pembuat Akta Tanah atau biasa disebut PPAT. Sebagaimana disebutkan dalam pasal 37 ayat (1) PP No. 24 
Tahun 1997 yang menjelaskan bahwa peralihan hak atas tanah baik melalui jual beli, hibah, tukar menukar dan sebagainya harus dibuktikan dengan akta yang dibuat PPAT jika akan dilakukan pendaftaran di Kantor Pertanahan. Namun dalam ayat (2) dijelaskan bahwa dalam rangka untuk mendaftar ke Kantor PertanahanKabupaten/ Kota, tidak mutlak harus dibuktikan dengan akta yang dibuat PPAT, namun dapat digantikan dengan akta lain yang dianggap telah mencukupi sebagai syarat dilakukannya pendaftaran. Hal ini dilakukan hanya karena adanya suatu keadaan tertentu, tetapi tidak diatur secara rinci mengenai definisi dari keadaan tertentu yang dimaksud. Keharusan pembuatan akta jual beli di PPAT ini bukan hanya untuk memperoleh keabsahan pendaftaran peralihan hak atas tanah tetapi berhubungan juga dengan penarikan Bea Perolehan Hak Atas Tanah dan Bangunan (BPHTB). Pemberlakuan ini dimulai sejak diterbitkannya UU No. 21 tahun 1997 tentang Bea Perolehan Hak Atas Tanah dan Bangunan (BPHTB).

Pembuatan akta jual beli di PPAT, tidak diharuskan tanah tersebut sudah bersertipikat, tanah yang belum bersertipikat pun bisa dilakukan. Jika jual beli tanah tidak ada niatan untuk didaftarkan, maka akta jual beli boleh dibuat diatas tangan dalam artian di buat di hadapan kepala desa dengan disertai materai, namun jika nantinya berniat untuk didaftarkan di Kantor Pertanahan Kabupaten/Kota, maka pembuatan akta PPAT menjadi suatu keharusan. Semenjak diterbitkannya UU No. 21 tahun 1997, pembuatan akta jual beli di PPAT menjadi keharusan dikarenakan pemindahan hak ini berkaitan dengan penarikan BРHTB.

Ketentuan dari PPAT diatur tersendiri dalam PP No. 37 tahun 1998 dan dirubah dengan PP No. 24 tahun 2016 ttentang Peraturan Jabatan Pejabat Pembuat Akta Tanah. PPAT sendiri merupakan pejabat umum yang diberi kewenangan untuk membuat akta otentik terkait dengan perbuatan hukum tertentu terhadap hak atas tanah dan hak milik atas satuan rumah susun. Jika pada suatu daerah belum cukup terdapat PPAT, maka kepala kecamatan dapat ditunjuk sebagai PPAT sementara untuk bertindak sebagai pelaksana tugas dari PPAT. ${ }^{18}$

${ }^{18}$ Urip Santoso (n 5). Op.Cit.[370]. 
Dalam Kamus Besar Bahasa Indonesia (KBBI) istilah "Akta" memiliki arti surat tanda bukti berisi pernyataan (keterangan, pengakuan, keputusan dan sebagainya) tentang peristiwa hukum yang dibuat menurut peraturan yang berlaku, disaksikan dan disahkan oleh pejabat resmi. ${ }^{19}$ Dalam bahasa belanda, istilah akba disebut "acte/akta", sedangkan dalam bahasa inggris disebut (act/ deed), yang keduanya bermakna perbuatan dan suatu tulisan yang dibuat dan dipergunakan sebagai bukti perbuatan hukum. ${ }^{20}$

Menurut R. Subekti dan Tjitrisoedibio bahwa kata " $a c t a$ " merupakan bentuk jamak dari kata "actum" yang berasal dari bahasa latin dan memiliki makna perbuatan-perbuatan. ${ }^{21}$ Sementara Sudikno Mertokusumo mengartikan akta sebagai surat yang diberi tandatangan, yang memuat peristiwa-peristiwa yang menjadi dasar dari pada suatu hak atau perikatan, yang dibuat sejak semula dengan sengaja untuk keperluan pembuktian. ${ }^{22}$

Pasal 1867 KUH Perdata menyebutkan bahwa akta dibedakan menjadi 2 yaitu akta otentik dan akta di bawah tangan. Akta otentik ialah suatu akta yang dibuat dalam bentuk yang ditentukan undang-undang oleh atau dihadapan pejabat umum yang berwenang untuk itu di tempat akta itu dibuat. Dalam hal pencatatan terkait perbuatan hukum terhadap tanah, pejabat berwenang membuat akta adalah Pejabat Pembuat Akta Tanah (PPAT). Selain akta otentik, ada juga akta dibawah tangan, yang menurut KUH Perdata diartikan sebagai akta yang ditandatangani di bawah tangan, surat, daftar, surat urusan rumah tangga dan tulisan-tulisan yang lain yang dibuat tanpa perantaraan seorang pejabat umum. Pembuatan akta pemindahan hak di PPAT, mengindikasikan bahwa telah terjadi pemindahan hak atas tanah dari penjual kepada pembeli, dan untuk memenuhi asas pubisitas, maka dilakukan lah pendaftaran pemindahan hak di Kantor April 2020.

19 Kamus Besar Bahasa Indonesia, 'Akta' <https://www.kbbi.web.id/akta> accessed 20

20 Victor M Situmorang dan Cormentyna sitanggang, Aspek Hukum Akta Catatan Sipil Di Indonesia (Sinar Grafika 1991). [50].

${ }^{21}$ R. Subekti dan Tjitrosoedibio, Kamus Hukum (Pradya Paramita 1986). [5].

22 ibid.[5]. 
Pertanahan Kabupaten/Kota, sehingga informasi ini dapat diakses oleh umum. ${ }^{23}$ Peralihan hak atas tanah melalui jual beli dibuat dengan akta di PPAT, hal ini sesuai dengan bunyi pasal 37 ayat (1) PP No. 24 tahun 1997 namun pada ayat kedua dijelaskan bahwa untuk keperluan pendaftaran di Kantor Pertanahan peralihan hak atas tanah dapat dibuktikan dengan akta lain yang tidak dibuat di PPAT, tetapi yang menurut Kepala Kantor Pertanahan tersebut kadar kebenarannya dianggap cukup untuk mendaftar pemindahan hak yang bersangkutan.

\section{Keabsahan Jual Beli Tanah Terhadap Tanah yang Belum Bersertipikat}

Untuk mendapatkan jaminan hukum dan kepastian terhadap hak atas tanah, maka perlu dilakukan pendaftaran ke Kantor Pertanahan Kabupaten/

Kota. Pemegang hak atas tanah yang telah mendaftarkan tanahnya akan memperoleh surat tanda bukti hak bernama sertipikat. Terkait dengan tanah yang hanya dikuasai secara fisik, tanpa adanya bukti otentik, Undang-undang tidak mengatur perihal perlindungan hukum baginya. Namun hal itu bukan berarti pemilik tanah tidak akan memperoleh perlindungan hukum, tetapi jika ada bukti lain sebagaimana disebutkan dalam pasal 24 ayat (1) PP No. 24 tahun 1997 maka tanah tersebut bisa didaftarkan untuk pertama kali. Penguasaan tanah secara fisik saja tetap bisa didaftarkan dan diperoleh sertipikat dengan ketentuan pemilik tanah telah menguasai tanahnya selama 20 tahun secara berturut-turut dengan itikad baik. Selain itu juga disertakan surat keterangan dari Kepala Desa terkait penguasaan tanah oleh pemilik tanah beserta 2 orang saksi dari lingkungannya.

Jual beli tanah dicatat dan dibuatkan akta oleh PPAT jika bidang tanah tersebut mau didaftar ke Kantor Pertanahan guna memperoleh sertipikat sebagai bukti terkuat kepemilikan hak atas tanah. Jual beli tanah juga bisa dilakukan oleh Kepala Kecamatan yang sebelumnya telah dtunjuk sebagai PPAT sementara

${ }^{23}$ Urip Santoso (n 5). Op. Cit.[371]. 
dengan ketentuan daerah tersebut masih kurang adanya PPAT maka Kepala Kecamatan punya wewenang untuk menggantikan peran PPAT. ${ }^{24}$

\section{Konsep UUPA dan Hukum Adat}

Jual beli tanah yang dianut UUPA adalah menganut sistem hukum adat, dimana jual beli dalam sistem hukum adat harus memenuhi 3 unsur seperti yang dikemukakan Maria S.W. Sumardjono, myang mengatakan bahwa jual beli tanah di Indonesia menganut sistem hukum adat yang memiliki 3 sifat yakni $:{ }^{25}$

a. Tunai

Istilah tunai disini memiliki arti bahwa transaksi antara penyerahan hak atas tanah oleh pemilik tanah atau penjual dan pembayaran yang dilakukan oleh pembeli dilakukan dalam waktu yang bersamaan. Tidak ada suatu keharusan pembayaran dilakukan langsung lunas, tetapi jika pembeli hanya membayar sebagian saja itu sudah dianggap tunai, perihal kekurangan pembayaran diselesaikan dalam hukum utang piutang.

b. Riil

Niat untuk melakukan jual beli tanah diikuti dengan suatu tindakan nyata jual beli tanah. salah satu contohnya yaitu dengan pembuatan perjanjian di hadapan Kepala Desa setelah pembeli melakukan pembayaran kepada penjual.

c. Terang

Perbuatan hukum pemindahan hak, terutama dalam jual beli tanah dilakukan di hadapan Kepala Desa sebagai tanda bahwa perbuatan hukum ini bukan merupakan tindakan pelanggaran hukum yang berlaku.

Sementara itu Efendi Perangin sebagaimana dikutip Urip Santoso mengatakan bahwa jual beli tanah menurut hukum adat memiliki 2 sifat yaitu tunai dan terang. Tunai berarti penyerahan hak dan pembayaran dilakukan secara bersama. Bisa langsung tunai ataupun dibayar sebagian, dan hal itu sudah dianggap jual beli

\footnotetext{
${ }^{24}$ Ardiansyah Zulhadji, 'Peralihan Hak Atas Tanah Melalui Jual Beli' (2016) V Lex Crimen.[4].

${ }^{25}$ Urip Santoso (n 5). Op Cit.[361].
} 
telah selesai, mengenai kekurangan pembayaran dianggap sebagai utang piutang kedua pihak. ${ }^{26}$ Artinya jika pembeli tidak dapat melunasi pembayaran, maka hal ini jual beli tidak bisa dibatalkan, melainkan harus diselesaikan melalui perjanjian jual beli. Sementara terang berarti bahwa perjanjian dilakukan di hadapan kepala desa sebagai saksi sekaligus pihak yang menanggung bahwa jual beli tidak melanggar ketentuan hukum. Makna terang berarti bukan gelap, artinya pembeli mendapat pengakuan dari masyarakat. ${ }^{27}$

Konsep jual beli yang dimaksud dalam UUPA adalah sama dengan konsep jual beli tanah pada hukum adat, maka syarat sah dalam pelaksanaannya adalah sama pula. dalam hukum adat syarat sah jual beli tanah ialah tunai, riil, dan terang. Akibat hukum apabila jual beli terhadap tanah yang belum bersertipikat telah memenuhi unsur tunai, riil, dan terang, maka jual beli dianggap sah menurut hukum. Sebelum tahun 1997 tepatnya sebelum diterbitkannya UU No. 21 tahun 1997 tentang Bea Perolehan Hak Atas Tanah dan Bangunan (UUBPHTB), jual beli tanah cukup dilakukan dengan perjanian dibawah tangan yang dibuat oleh kedua belah pihak yang dibenarkan dan diketahui serta ditandatangani oleh kepala desa adalah sah. Kondisi berbeda setelah berlakunya UU No. 21 tahun 1997 dimana akta PPAT menjadi bukti yang kuat akan terjadinya jual beli terhadap bidang tanah dan menjadi syarat jika nantinya bidang tanah tersebut akan didaftarkan di Kantor Pertanahan perjanjian jual beli harus dilakukan pembuatan akta di PPAT dikarenakan pemindahan hak ini berkaitan dengan penarikan BPHTB. PPAT yang dalam pembuatan akta mengesampingkan pembayaran BPHTB dari pihak terkait jelas akan menimbulkan persoalan hukum juga karena tindakan tersebut diancam dengan sanksi administrasi dari Direktorat Jenderal Pajak/Kantor Pelayanan Pajak Bumi dan Bangunan dan juga sanksi dari kantor pertanahan.

Putusan Pengadilan Negeri Nomor : 19/Pdt.G/2015/PN.Mgg tanggal 27 Agustus 2015 yang telah memiliki kekuatan hukum tetap (inkracht) dengan

\footnotetext{
${ }^{26}$ Baiq Henni Paramita, 'Akibat Hukum Jual Beli Hak Atas Tanah Yang Belum Didaftarkan' (2016) IV Jurnal IUS.[360].

27 ibid.[361].
} 
penggugat atas nama Sumirah dan tergugat atas nama Martosarno, dimana pada intinya terjadi jual beli tanah antara suami penggugat dengan tergugat. Tanah yang dibeli belum bersertipikat, dan jual beli dilakukan dibawah tangan dengan ditandatangani kepala desa. Setelah suami penggugat meninggal, dan penjual sudah tidak diketahui keberadaannya, ia hendak mensertipikatkan tanahnya, namun ditolak karena jual beli hanya dilakukan dibawah tagan, sehinga penggugat akan membuat akta jual beli di PPAT. Namun tidak terealisasi karena tergugat sudah tidak diketahui keberadaannya. Kemudian penggugat memperkaraan di penadilan dengan menggugat penjual dan memohon untuk diberikan legalitas jual beli tanah dibawah tangan yang sudah dibuat pada saat transaksi. Hakim memutuskan surat perjanjian jual beli dibawah tangan sah dan berharga, sehingga bisa langsung didaftarkan ke Kantor Pertanahan.

Berdasarkan putusan pengadilan di atas, kurang tepat jika dijadikan acuan dalam proses untuk mendaftarkan di Kantor Pertanahan. Mulai berlakunya PP No. 21 tahun 1997 membuat semua proses jual beli tanah harus didaftarkan di PPAT. Kasus posisi atau peristiwa hukum dalam putusan pengadilan tersebut terjadi pada tahun 1968, dimana pada masa itu jual beli tanah cukup dilakukan dengan dibawah tangan, sesuai dengan ketentuanj pasal 37 ayat (2) PP No. 24 tahun 1997 yang memberi kelonggaran lain terkait jual beli tanah yang tidak harus dibuat di PPAT melainkan di bawah tangan dengan syarat dan ketentuannya dianggap memenuhi oleh Badan Pertanahan Nasional. Jual beli terhadap bidang tanah yang belum bersertipikat tetap bisa didaftarkan di PPAT. Pertimbangan hakim yang menjadi intinya yaitu ketiadaan salah satu pihak dengan alasan yang dapat diterima. Hakim memutuskan bahwa jual beli yang dilakukan dibawah tangan dapat ialah sah dan berharga, serta dengan perjanjian di bawah tangan yang dibuat kedua pihak tersebut dapat dijadikan alas untuk dilakukan pendaftaran di Kantor Pertanahan. Konteks ini harus diperhatikan, mengingat pertimbangan utamanya ialah ketiadaan dari salah satu pihak. 


\section{Kesimpulan}

Hak atas tanah yang hanya dikuasai hanya secara fisik tanpa adanya bukti tertulis sebagaimana disebutkan dalam penjelasan pasal 24 PP No. 24 tahun 1997 bisa dilakukan pendaftaran tanah. Melalui mekanisme pendaftaran tanah untuk pertama kali, dan dengan membuat surat keterangan bahwa yang bersangkutan telah menguasai tanah selama 20 tahun secara berturut-turut dan juga ditandatangani kepala desa serta 2 orang saksi.Hasil akhir dari pendaftaran tanah ini adalah dengan diterbitkannya sertipikat hak atas tanah yang merupakan bukti terkuat pembuktian penguasaan hak atas tanah.

Dengan dasar bahwa pembentukan UUPA sebagai induk peraturan yang mengatur tentang pertanahan mengadopsi dari hukum adat, maka pelaksanaanjual beli di Indonesia menggunakan konsepsi, asas-asas, lembaga hukum, dan sistem yang dianut oleh hukum adat. Jual beli tanah menurut hukum adat menggunakan syarat terang, riil, dan tunai. Ketentuan ini juga berlaku bagi tanah yang belum terdaftar atau belum bersertipikat, jika jual beli telah memenuhi persyaratan, jual beli terhadap tanah yang belum bersertipikat adalah sah menurut hukum. Terkait dengan penarikan BPHTB, maka setelah diterbitkannya UU No. 21 tahun 1997, jual beli tanah harus dilakukan dengan akta jual beli yang dibuat di PPAT, sebagai pejabat yang berwenang sebagaimana dijelaskan dalam pasal 37 ayat (1) PP No. 24 tahun 1997. Terhadap bidang tanah yang menjadi objek jual beli tanah belum bersertipikat, tetap bisa dilakukan pembuatan akta jual Beli di PPAT.

\section{Daftar Bacaan}

\section{Buku}

Adrian Sutedi, Peralihan Hak Atas Tanah Dan Pendaftarannya (Sinar Grafika 2010).

M. Yamin Lubis dan Abd. Rahim Lubis, Hukum Pendaftaran Tanah (Mandar Maju 2018).

R. Subekti dan Tjitrosoedibio, Kamus Hukum (Pradya Paramita 1986).

Samun Ismaya, Hukum Administrasi Pertanahan (Graha Ilmu 2013). 
Soerjono Soekanto \& Sri Mamudji, Penelitian Hukum Normatif (Suatu Tinjauan Singkat) (Rajawali Pers 2001).

Urip Santoso, Pendaftaran Dan Peralihan Hak Atas Tanah (Prenamedia Group 2010).

Victor M Situmorang dan Cormentyna sitanggang, Aspek Hukum Akta Catatan Sipil Di Indonesia (Sinar Grafika 1991).

\section{Jurnal}

Ardiansyah Zulhadji, 'Peralihan Hak Atas Tanah Melalui Jual Beli' (2016) V Lex Crimen.

Baiq Henni Paramita, 'Akibat Hukum Jual Beli Hak Atas Tanah Yang Belum Didaftarkan' (2016) IV Jurnal IUS.

Ilyas Ismail, 'Sertifikat Sebagai Alat Bukti Hak Atas Tanah Dalam Proses Peradilan' [2011] XIII Kanun Jurnal Ilmu Hukum.

\section{Laman}

Direktorat Jenderal Bina Administrasi Kewilayahan, 'Data Rekapitulasi Jumlah Pulau' <https://ditjenbinaadwil.kemendagri.go.id/wp-content/ uploads/2019/01/3.-Data-Rekapitulasi-Jumlah-Pulau> accessed 27 August 2019.

Kamus Besar Bahasa Indonesia, 'Akta' <https://www.kbbi.web.id/akta> accessed 20 April 2020.

— - 'Jual Beli' <https:/ / www.kbbi.web.id/jual beli> accessed 12 April 2020.

Kementerian ATR/BPN, 'Infografis Pendaftaran Data Pendaftaran Tanah Di Indonesia' <https://www.atrbpn.go.id/Berita/Infografis> accessed 29 August 2019.

How to cite: Mohamad Da'i Efendi, 'Penguasaan Hak Atas Tanah yang Belum Bersertipikat' (2020) Vol. 3 No. 3 Notaire. 